\title{
USING THE FALSE CLAIMS ACT TO REMEDY TAX-EXPENDITURE FRAUD
}

\author{
IAN AYRES $\dagger \&$ ROBERT MCGUIRE $\dagger \dagger$
}

\begin{abstract}
The federal False Claims Act (FCA) may be a tool for combating fraudulent claims regarding tax expenditures. The FCA has been used to protect the public fisc by imposing liability upon anyone who makes a false or fraudulent claim relating to an expenditure of federal funds. A substantial share of government spending is implemented through tax credits and deductions granted to individuals and entities for taking particular actions promoted by the tax code-so-called "tax expenditures." Funds subsidized by such tax expenditures can themselves be the objects of fraud. For example, a taxpayer could be defrauded of retirement funds that the government has indirectly subsidized through tax deductions granted to the defrauded taxpayer. This Article explores how the FCA might be invoked to combat fraud that targets the recipients of tax expenditures, as well as doctrinal counterarguments to such an application. We touch on the potential breadth of the FCA's reach insofar as it encompasses such claims, as well as the prospect of using other whistleblower mechanisms to achieve similar results.
\end{abstract}

\section{INTRODUCTION}

The government can create incentives for private action by either granting subsidies or reducing taxes on desired behaviors. ${ }^{1}$ The

Copyright (C) 2016 Ian Ayres and Robert McGuire.

$\dagger$ Townsend Professor, Yale Law School.

†† Robert McGuire is an attorney whose litigation practice includes representing qui tam relators under the False Claims Act. McGuire himself served as a qui tam relator in United States ex rel. McGuire v. Webster Bank, N.A., No. 14-cv-00097-RM-CBS (D. Colo. Sept. 3, 2015), a case that involved claims brought under both the FCA and the New York False Claims Act which tested the theories advanced by this Article. We are thankful to Ahsan Barkatullah for excellent research assistance.

1. While both direct subsidies and tax preferences can be used to offer the proverbial carrot, by creating rewards contingent upon action, the government may also employ the proverbial stick, and instead use contingent punishments to disincentivize failure to act. See, e.g., Ian Ayres \& Amy Kapczynski, Innovation Sticks: The Limited Case for Penalizing Failures to Innovate, 82 U. CHI. L. REV. 1781, 1782-89 (2015). 
government "spends" money when it gives individuals and entities tax credits and deductions for taking particular actions, because it foregoes $\operatorname{tax}$ revenue. These so-called "tax expenditures" by the federal government have been estimated to cost over one trillion dollars annually-an amount that rivals all discretionary direct spending. ${ }^{2}$

This Article argues that tax expenditures, like direct expenditures, should be protected against false and fraudulent claims. If a health-care provider's fraud inflates employer contributions for medical insurance premiums - which are not taxed - the government's interest is injured just as much as it would be in a run-of-the-mill federal False Claims Act (FCA) case involving a more traditional form of fraud. ${ }^{3}$ Historically, the FCA has been used to protect the public fisc by creating liability against anyone who makes a false or fraudulent claim relating to a direct expenditure of federal funds. But we argue that the FCA might also be used to combat fraud that targets government spending in the form of tax expenditures.

Although taxpayers themselves may defraud the government by making false claims for tax credits or deductions, this Article focuses on fraud committed against taxpayers by third parties who target the government-subsidized funds in the hands of those taxpayers. Such "third-party" fraud against taxpayers in their capacity as claimants or recipients of government tax expenditures does not just harm those taxpayers. It also undermines the government's programmatic goal in granting the tax expenditure in the first place, whether that goal is to encourage employer spending on health plans, to promote home ownership, or some other public policy purpose. These third-party frauds against taxpayers are economically indistinguishable from thirdparty frauds against contractors, grantees, and other direct recipients of government money. ${ }^{4}$ In 1986, when Congress enacted the modern

2. See infra note 53 and accompanying text.

3. Knowingly selling the government guns that do not shoot is an example of the kind of fraud that is traditionally actionable under the FCA. See Universal Health Servs., Inc. v. United States ex rel. Escobar, 136 S. Ct. 1989, 2001 (2016) (using this example).

4. While tax expenditures are economically indistinguishable from direct expenditures, these two forms of financial subsidies are readily distinguishable politically. Unlike direct expenditures, tax expenditures are off-budget spending and, as such, are often portrayed as tax cuts rather than as spending increases. Because the former is more politically palatable than the latter, amending the FCA to explicitly cover tax-expenditure fraud could present Congress with a relatively (politically) costless way to generate a nontrivial amount of additional revenue. In fiscal year 2015 alone, for example, the government obtained more than $\$ 3.5$ billion in settlements and judgments from civil cases involving fraud and false claims against the government. See Justice Department Recovers Over $\$ 3.5$ Billion from False Claims Act Cases in Fiscal Year 2015, U.S. 
version of the law, it clearly made third-party fraud against contractors, grantees, and "other recipients" of federal funds a target of the FCA. ${ }^{5}$ Accordingly, we argue that fraud against taxpayer-claimants-who, being economically indistinguishable from direct recipients of government money, are properly deemed "other recipients"-should also be actionable under the FCA.

This Article explores how the FCA might be invoked to combat fraud that targets government spending in the form of tax expenditures, as well as doctrinal counterarguments to such an application. We touch on the potential breadth of the FCA's reach insofar as it encompasses such claims, as well as the prospect of amending the FCA or using other whistleblower mechanisms to achieve similar results.

The Article is organized in three parts. Part I introduces the FCA. Part II explains the concept of a tax expenditure. Part III argues that claims under the FCA should include fraud relating to government spending in the form of tax expenditures. There, we analyze two cases that appear to reject the application of the FCA to tax-expenditure fraud, use our analysis of the case law to refute concerns relating to our tax-expenditure theory, and describe some areas where the taxexpenditure theory may be used. Finally, we conclude that our approach could allow the federal government to extend the anti-fraud protections of the FCA to cover for the first time more than one trillion dollars of spending that is accomplished through the tax code.

DEP'T OF JUSTICE (Dec. 3, 2015), https://www.justice.gov/opa/pr/justice-department-recoversover-35-billion-false-claims-act-cases-fiscal-year-2015 [https://perma.cc/Z9YA-JYJQ]. In 2014, FCA recoveries approached a whopping \$6 billion. See Justice Department Recovers Nearly \$6 Billion from False Claims Act Cases in Fiscal Year 2014, U.S. DEP'T OF JUSTICE (Nov. 20, 2014), http:/www.justice.gov/opa/pr/justice-department-recovers-nearly-6-billion-false-claims-act-cases -fiscal-year-2014 [https://perma.cc/L6QQ-TYCK]. Because of the relative parity of tax expenditures and direct discretionary spending in the federal budget, see infra note 53 and accompanying text, it is not unreasonable to imagine that comparable recoveries could result if the FCA were applied to tax-expenditure fraud.

5. See S. REP. NO. 111-10, at 11-12 (2009), reprinted in 2009 U.S.C.C.A.N. 430, 438-39, 439 $\mathrm{n} .4$ (discussing "[f]raud against government contractors and grantees"); S. REP. No. 99-345, at 22 (1986), reprinted in 1986 U.S.C.C.A.N. 5266, 5287 ("Thus, the Committee intends . . to overrule Azzarelli and similar cases which have limited the ability of the United States to use the act to reach fraud perpetrated on federal grantees, contractors or other recipients of Federal funds."). 


\section{History OF THE FALSE Claims ACT}

The law that became today's FCA was enacted on March 2, 1863, ${ }^{6}$ in an effort to combat "rampant fraud in Civil War defense contracts,"? through which war profiteers supplied the United States with everything from shoddy uniforms to spoiled meat and blind horses, all at exorbitant prices. ${ }^{8}$ The FCA targets false and fraudulent claims and includes an ancient legal device called a "qui tam" provision that allows a private plaintiff, called a "relator," to sue on behalf of the United States to enforce the provisions of the statute without having personally suffered harm. ${ }^{9}$

From its inception, the FCA "was intended to reach all types of fraud, without qualification, that might result in financial loss to the Government." ${ }^{10}$ The Supreme Court has acknowledged that Congress's purpose in passing the FCA "was broadly to protect the funds and property of the Government from fraudulent claims, regardless of the particular form, or function, of the government instrumentality upon which such claims were made." ${ }^{11}$ In other words, the "Act's primary purpose is to indemnify the government - through

6. An Act to Prevent and Punish Frauds Upon the Government of the United States (False Claims Act), ch. 67, 12 Stat. 696 (1863).

7. S. REP. NO. 99-345, at 8 (1986), reprinted in 1986 U.S.C.C.A.N. 5266, 5273.

8. See Ron Soodalter, The Union's 'Shoddy' Aristocracy, N.Y. TIMES (May 9, 2011), http://opinionator.blogs.nytimes.com/2011/05/09/the-unions-shoddy-aristocracy [https://perma. cc/T9J2-2VCJ]. The use of the term "shoddy" to denote "having a delusive appearance of high quality" stems from the practice of Civil War contractors selling the Army and Navy clothes made out of a kind of rag-wool padding which "when new . . looked like broad-cloth," but whose "gloss quickly wore off, giving the stuff a bad reputation as a cheat." Shoddy, ONLINE ETYMOLOGY DICTIONARY, http:/www.etymonline.com/index.php?term=shoddy [https:/perma.cc/F3CMWPY6].

9. 31 U.S.C. $\$ 3730($ b) (2012). The term "'qui tam' is short for 'qui tam pro domino rege quam pro se ipso in hac parte sequitur,' which means 'who pursues this action on our Lord the King's behalf as well as his own." Rockwell Int'l Corp. v. United States, 549 U.S. 457, 463 n.2 (2007).

10. United States v. Neifert-White Co., 390 U.S. 228, 232 (1968).

11. Rainwater v. United States, 356 U.S. 590, 592 (1958); see United States v. McNinch, 356 U.S. 595 (1958). The McNinch court explained:

The False Claims Act was originally adopted following a series of sensational congressional investigations into the sale of provisions and munitions to the War Department. Testimony before the Congress painted a sordid picture of how the United States had been billed for nonexistent or worthless goods, charged exorbitant prices for goods delivered, and generally robbed in purchasing the necessities of war. Congress wanted to stop this plundering of the public treasury.

McNinch, 356 U.S. at 599 (footnote omitted). 
its restitutionary penalty provisions-against losses caused by a defendant's fraud." $" 12$

By providing successful relators with a share of the government's recovery, the FCA incentivizes relators with knowledge of fraud to come forward and, if necessary, prosecute cases on the government's behalf. The relator's share is generally $15-25$ percent of the government's total recovery in cases in which the government intervenes, and 25-30 percent when the government does not intervene..$^{13}$

\section{A. Liability Under the FCA}

In order to establish a traditional prima facie FCA violation, a plaintiff must prove that "(1) the defendant presented or caused to be presented to an agent of the United States a claim for payment; (2) the claim was false or fraudulent; and (3) the defendant knew the claim was false or fraudulent." 14

The FCA has historically been used to protect federal funds in a wide range of contexts. ${ }^{15}$ For example, in United States $v$. Veneziale, ${ }^{16}$ the government alleged that the defendant caused certain individuals to make a fraudulent application for a bank loan by falsely representing that the loan was for home improvements, whereas the actual purpose of the loan was to purchase real property from the defendant. ${ }^{17}$ The Federal Housing Administration relied on the false application, among other documents, when it guaranteed repayment of the loan. ${ }^{18} \mathrm{~A}$ partial default on the loan led the government to pay under that guarantee. ${ }^{19}$ The Third Circuit held that "the government, having been compelled to pay an innocent third person as a result of the defendant's

12. Mikes v. Straus, 274 F.3d 687, 696 (2d Cir. 2001).

13. 31 U.S.C. $\$ 3730$ (d).

14. United States ex rel. Wilkins v. United Health Grp., Inc., 659 F.3d 295, 304-05 (3d Cir. 2011). Since 2009, presentment of a claim for payment to the government itself has not been required. See infra notes 33-36 and accompanying text.

15. See Neifert-White, 390 U.S. at 232 ("In the various contexts in which questions of the proper construction of the Act have been presented, the Court has consistently refused to accept a rigid, restrictive reading, even at the time when the statute imposed criminal sanctions as well as civil.").

16. United States v. Veneziale, 268 F.2d 504 (3d Cir. 1959).

17. Id. at 504-05.

18. Id. at 504 .

19. Id. at 504-05. 
fraud in inducing the undertaking, is entitled to assert a claim against the defendant under the False Claims Act." ${ }^{20}$

In Scolnick $v$. United States, ${ }^{21}$ the First Circuit held that the "endorsement and deposit for collection of a government check known to be issued by mistake in payment of an obligation already, in fact, satisfied... [was] the presentation of a false claim within the meaning of the False Claims Act." ${ }^{\prime 22}$ In this case, the officer of a corporation was liable under the FCA for claiming funds from the government on behalf of the corporation, even in the absence of any "direct personal benefits to the defendant."23

In Alperstein v. United States, ${ }^{24}$ the Fifth Circuit considered whether false statements related to a veteran's application for treatment in a veterans' hospital were "false 'claims,' 'certificates,' or 'affidavits,' used for the purpose of obtaining payment of a 'claim upon or against the Government of the United States.",25 It held that "the filing of [the] false affidavit and application for hospitalization, involving ... immediate outlay by the Government of substantial sums of money and the receipt by the patient of services, facilities, food and drugs of substantial cost to the Government, [fell] within the purview of the False Claims Act." ${ }^{26}$

In recent years, the size of FCA recoveries has become quite significant. A person found guilty of violating the FCA is liable for a civil penalty as well as treble damages. ${ }^{27}$ Enforcement of the FCA has

20. Id. at 506 .

21. Scolnick v. United States, 331 F.2d 598 (1st Cir. 1964).

22. Id. at 599 .

23. Id.

24. Alperstein v. United States, 291 F.2d 455 (5th Cir. 1961).

25. Id. at 456 .

26. Id.

27. 31 U.S.C. $\$ 3729$ (a)(1) (2012). A person violates the FCA when he

(A) knowingly presents, or causes to be presented, a false or fraudulent claim for payment or approval;

(B) knowingly makes, uses, or causes to be made or used, a false record or statement material to a false or fraudulent claim; ....

(D) has possession, custody, or control of property or money used, or to be used, by the Government and knowingly delivers, or causes to be delivered, less than all of that money or property;

$\cdots$

$\ldots$ or

(G) knowingly makes, uses, or causes to be made or used, a false record or statement material to an obligation to pay or transmit money or property to the Government, or knowingly conceals or knowingly and improperly avoids or 
enabled the government to recoup more than $\$ 3.5$ billion in each of the last four fiscal years. ${ }^{28}$ One reason the government's annual recoveries have been so large is that Congress modernized and strengthened the FCA in 1986 in order "to enhance the Government's ability to recover losses sustained as a result of fraud" and "to make the statute a more useful tool against fraud in modern times." 29

Among other changes made in 1986 , Congress expressly defined the term "claim" for the first time, clarifying that "claims" subject to the FCA include requests or demands for money or property submitted to a "contractor, grantee, or other recipient if the United States Government provides any portion of the money or property which is requested or demanded." ${ }^{30}$ Congress explicitly chose this language to ensure that the FCA would not be limited to fraud perpetrated directly against the government itself, but also "reach fraud perpetrated on federal grantees, contractors or other recipients of Federal funds." 31 For example, the 1986 amendments ensured that fraud against private intermediaries such as insurance companies, which resulted in expenditures by the Medicare or Medicaid programs, would be subject to the FCA. ${ }^{32}$

Although one express goal of the 1986 amendments was to enhance the FCA as a tool for combatting fraud, from 1986 to 2009, courts frequently construed the FCA in ways that limited the law's reach. Of particular relevance to our tax-expenditure theory, courts interpreted the FCA to require that a fraudulent request for payment must actually be presented to the government itself-even in those actions based upon false claims made by a third party to contractors, grantees, or other intermediary recipients of government money ${ }^{33}$ This

decreases an obligation to pay or transmit money or property to the Government ....

Id. The four quoted violations are those that we believe lend themselves most easily to addressing tax-expenditure fraud.

28. See supra note 4.

29. S. REP. No. 99-345, at 1 (1986), reprinted in 1986 U.S.C.C.A.N. 5266, 5266.

30. Pub. L. No. 99-562, 100 Stat. 3153, 3154 (1986) (current version at 31 U.S.C. $\S 3729$ (b)(2) (defining "claim")).

31. S. REP. No. 99-345, at 22.

32. The legislative history of the 1986 amendments states that the amendments clarify the FCA application to frauds perpetrated against Medicare and Medicaid funds, notwithstanding the fact that "claims are not submitted directly to the Federal agency, but rather to private intermediaries." Id. at 21.

33. See United States ex rel. Totten v. Bombardier Corp., 380 F.3d 488, 502 (D.C. Cir. 2004); see also Allison Engine Co. v. United States ex rel. Sanders, 553 U.S. 662, 672 (2008) (agreeing with Totten, and stating that " $[\mathrm{r}]$ ecognizing a cause of action under the FCA for fraud directed at 
construction did not accord with the intention expressed by Congress when the 1986 amendments were adopted.

On May 20,2009, reacting in part to such narrow interpretations of the FCA, Congress passed the Fraud Enforcement Recovery Act of 2009 (FERA). ${ }^{34}$ In the FERA, Congress redefined "claim" to mean

(A) ... any request or demand, whether under a contract or otherwise, for money or property and whether or not the United States has title to the money or property, that-

(i) is presented to an officer, employee, or agent of the United States; or

(ii) is made to a contractor, grantee, or other recipient, if the money or property is to be spent or used on the Government's behalf or to advance a Government program or interest, and if the United States Government -

(I) provides or has provided any portion of the money or property requested or demanded; or

(II) will reimburse such contractor, grantee, or other recipient for any portion of the money or property which is requested or demanded; and

(B) does not include requests or demands for money or property that the Government has paid to an individual as compensation for Federal employment or as an income subsidy with no restrictions on that individual's use of the money or property .... ${ }^{35}$

The FERA also removed language from the FCA that courts had relied on to require that a claim be presented to the government by an intermediary, if not by the claimant, in order to give rise to FCA liability. ${ }^{36}$

private entities would threaten to transform the FCA into an all-purpose antifraud statute"). But see United States ex rel. Sanders v. Allison Engine Co., 471 F.3d 610, 616 (6th Cir. 2006) (disagreeing with Totten), vacated, Sanders, 553 U.S. 662.

34. Fraud Enforcement Recovery Act of 2009, Pub. L. No. 111-21, § 386, 123 Stat. 1617, 1621-22 (codified as amended at 31 U.S.C. $\$ 3729$ ).

35. 31 U.S.C. $\$ 3729$ (b)(2) (2012).

36. Compare 31 U.S.C. $\$ 3729(\mathrm{a})(1)$ (2006) (pre-FERA) (imposing liability on a claimant who "knowingly presents, or causes to be presented, to an officer or employee of the United States Government ... a false or fraudulent claim for payment or approval"), with 31 U.S.C. $\S 3729$ (a)(1)(A) (2012) (post-FERA) (requiring only that the claimant "knowingly presents, or causes to be presented, a false or fraudulent claim for approval"). See also S. REP. NO.111-10, at 10 (2009), reprinted in 2009 U.S.C.C.A.N. 430, 438 ("This section amends the FCA to clarify and 
For purposes of our tax-expenditure theory, these amendments to the FCA are significant. The changes that Congress made in 1986 and reinforced in 2009 clarify that

liability ... attaches whenever a person knowingly makes a false claim to obtain money or property, any part of which is provided by the Government without regard to whether the wrongdoer deals directly with the Federal Government; with an agent acting on the Government's behalf; or with a third party contractor, grantee, or other recipient of such money or property. ${ }^{37}$

Moreover, federal courts have recognized that the FERA accomplished what Congress intended-extending the protections of the FCA to false claims made against government funds in the hands of third-party entities such as Freddie Mac and Fannie Mae, under the rubric of their being "contractor[s], grantees, or other recipient[s]" of government money. ${ }^{38}$

\section{B. The FCA's Tax Bar}

It is important to note that not all fraud involving tax expenditures is capable of giving rise to an action under the FCA. The FCA's scope is cabined by the statute's jurisdictional "Tax Bar." ${ }^{39}$ The Tax Bar provides that the FCA does not extend to "claims, records, or statements made under the Internal Revenue Code of 1986." ${ }^{40}$ This language prevents the FCA from being invoked against taxpayers who have themselves defrauded the government by falsely claiming tax deductions or tax credits.

correct erroneous interpretations of the law that were decided in [Allison Engine Co.] and [Totten].").

37. S. REP. NO. 111-10, at 11 .

38. See United States ex rel. Adams v. Aurora Loan Servs., Inc., 813 F.3d 1259, 1261 (9th Cir. 2016) (noting that a claim for defrauding Fannie Mae and Freddie Mac could be stated because $\S 3729$ (b)(2)(A)(ii) of the post-FERA FCA "defines a claim as a request or demand made upon non-governmental third parties under certain conditions," but affirming the claim's dismissal on the ground that the relator-appellants did not invoke that prong of the definition of "claim"); see also United States v. Countrywide Fin. Corp., 961 F. Supp. 2d 598, 609 (S.D.N.Y. 2013) (recognizing that FERA "arguably extends the FCA to false claims made to Fannie Mae and Freddie Mac," but dismissing the FCA claims on other grounds). But see United States ex rel. Todd v. Fidelity Nat'1 Fin., Inc., No. 1:12-CV-666-REB-CBS, 2014 WL 4636394, at *10-11 (D. Colo. Sept. 16, 2014) (acknowledging Countrywide's holding, but finding that the plaintiff had failed to allege the requisite nexus between the funds that Freddie Mac received from the government and the funds that Freddie Mac used to pay the alleged false claim).

39. 31 U.S.C. $\$ 3729$ (d) (2012).

40. Id. 
The seminal case applying the FCA's Tax Bar is United States ex rel. Lissack v. Sakura Global Capital Markets, Inc. ${ }^{41}$ There, the Second Circuit held that the purpose of the Tax Bar was straightforward-to prevent qui tam enforcement of the tax code. ${ }^{42}$ Lissack involved FCA claims related to a complicated "yield-burning" scheme that deprived the government of no-cost borrowing and caused it to pay excess interest on Treasury securities. ${ }^{43}$ The question presented was whether the Tax Bar applied "where the relator does not, strictly speaking, seek to recover federal taxes, but where the falsity of the underlying claim depends upon a violation of the Tax Code." ${ }^{44}$ Concluding that the purpose of the Tax Bar was to preserve the exclusive authority of the Internal Revenue Service (IRS) to enforce the tax code, the Second Circuit fashioned a two-prong test that precluded Lissack's FCA action because: (1) the "falsity of the claim . . . depends entirely upon establishing a violation of the Tax Code," and (2) "the IRS has authority to recover" the amount sought in the FCA action. ${ }^{45}$

Lissack's two-part test thus effectively only precludes FCA claims concerning frauds that are perpetrated by taxpayers. Accordingly, the Tax Bar presents no obstacle to using the FCA to combat fraud against taxpayers - i.e., fraud of a third party who targets taxpayer funds that have been subsidized by government tax expenditures. ${ }^{46}$

\section{TAX EXPENDITURES}

The current form of the FCA serves as a potentially formidable tool for combatting what we characterize as tax-expenditure fraud. Tax-expenditure fraud is accomplished by submitting a false request or demand for payment to a taxpayer that will be satisfied by the taxpayer using funds that are linked to a credit or deduction granted to the taxpayer under the tax code. Following the 2009 amendments designed to eliminate the presentment-to-government requirement in the context of claims made to contractors, grantees, and other recipients of

41. United States ex rel. Lissack v. Sakura Glob. Capital Mkts., Inc., 377 F.3d 145 (2d Cir. 2004).

42. See id. at 152-53 ("[The Tax Bar] was intended to codify case law existing before the 1986 amendment, which reserved discretion to prosecute tax violations to the IRS and barred FCA actions based on tax violations.").

43. Id. at 151 .

44. Id. at 153 .

45. Id. at 157.

46. For a discussion explaining why tax-expenditure fraud need not implicate the FCA's Tax Bar in the context of a particular case, see infra notes 121-22 and accompanying text. 
federal money, the FCA now arguably protects the government against fraud related to government spending in the form of tax expenditures.

The concept of tax expenditures first came to prominence on November 15, 1967, when Stanley Surrey, the Assistant Secretary of the Treasury for Tax Policy, gave a speech that called for the creation of a "tax expenditure budget" to obtain a full accounting of the effects of the tax system on federal budgeting. ${ }^{47}$ Since Surrey brought attention to the concept, both the federal government and more than two-thirds of the states have produced regular tax-expenditure budgets. $^{48}$

The Congressional Budget and Impoundment Control Act of 1974 defines tax expenditures as "revenue losses attributable to provisions of the federal tax laws which allow a special exclusion, exemption, or deduction from gross income or which provide a special credit, a preferential rate of tax, or a deferral of tax liability."49 Tax expenditures, therefore, are the costs borne by the government of preferential reductions in tax liabilities that arise from specific provisions of the tax code.

The Joint Committee on Taxation notes that tax expenditures are "analogous to direct outlay programs and may be considered alternative means of accomplishing similar budget policy objectives." 50 Because tax expenditures are available to all recipients who meet the required statutory criteria, programs funded by tax expenditures are "similar to direct spending programs that function as entitlements." 51

Tax expenditures can be measured by "the difference between tax liability under present law and the tax liability that would result from a recomputation of tax without benefit of the tax expenditure provision," or, alternately, as an "outlay equivalent" - "the dollar size of a direct spending program that would provide taxpayers with net benefits that

47. Stanley S. Surrey, Pathways to Tax Reform: The Concept of TaX EXPENDITURES 3-4 (1973).

48. Pub. L. No. 93-344, 88 Stat. 297, 323 (1974) (current version at 2 U.S.C. $\$ 632(\mathrm{e})(2)(E)$ (2012)); NAT'L CONFERENCE OF STATE LEGISLATURES, TAX EXPENDITURE BUDGETS AND REPORTS: BEST PRACTICES 1 (2014), http://www.ncsl.org/documents/task_forces/Tax _ Expenditure_Report.pdf [https://perma.cc/EA25-23HS].

49. Congressional Budget and Impoundment Control Act of 1974, Pub. L. No. 93-344, \& 3(3), 88 Stat. 297, 299 (codified as amended at 2 U.S.C. $\$ 622(3)$ ).

50. JOINT COMM. ON TAXATION, ESTIMATES OF FEDERAL TAX EXPENDITURES FOR FISCAL YEARS 2015-2019, at 2 (2015), https://www.jct.gov/publications.html?func+startdown $\&$ id $=4857$ [https://perma.cc/6QH4-VKLC].

51. Id. at 21 . 
would equal what they now receive from a tax expenditure." 52 In fiscal year 2014, the U.S. Government Accountability Office estimated that the sum of revenue losses attributable to tax expenditures was nearly $\$ 1.17$ trillion-essentially the equivalent of all federal discretionary direct spending. ${ }^{53}$ The Office of Management and Budget identified some of the largest tax-expenditure programs in fiscal year 2016 as the exclusion from taxation of employer contributions for medical insurance premiums and medical care ( $\$ 211$ billion), the exclusion from taxation of net imputed rental income ( $\$ 101$ billion), the preferential taxation of certain capital gains ( $\$ 93$ billion), and the home mortgage interest deduction ( $\$ 62$ billion). ${ }^{54}$

An example may help to illustrate the equivalency between tax expenditures and direct-outlay programs. Suppose that an individual has a gross income of $\$ 100$ and the tax rate is 30 percent. Further suppose that there are two possible scenarios: either the government gives a tax credit of $\$ 20$ for eligible medical expenses, or the government provides a direct, nontaxable subsidy of $\$ 20$ for the same eligible medical expenses. Table 1 below illustrates the effect of the government's choice of funding mechanism on both the taxpayer's income and the federal budget under each scenario.

52. Id. at $21 \&$ n. 27 .

53. U.S. GOV'T ACCOUNTABILITY OFFICE, CHART OF DISCRETIONARY SPENDING, MANDATORY SPENDING AND REVENUE LOSSES ATTRIBUTABLE TO TAX EXPENDITURES FROM 1984 TO 2014, http://www.gao.gov/assets/670/664912.pdf [https://perma.cc/9D4U-R5X4].

54. OFFICE OF MGMT. \& BUdGeT, ANALYTICAL PERSPECTIVES, BudgET OF THE UNITED STATES GOVERNMENT, FISCAL YEAR 2017, at 243, https:/www.whitehouse.gov/sites/default/ files/omb/budget/fy2017/assets/spec.pdf [https://perma.cc/TT29-89UH]; OFFICE OF MGMT. \& BudGeT, ANALYTICAL PERSPECTIVES, TAX EXPENDITURES, https://www.whitehouse.gov/sites/ default/files/omb/budget/fy2017/assets/ap_14_expenditures.pdf [https:/perma.cc/T5EX-UAQX]. 
Table 1. Economic Equivalence of Tax Expenditures and Direct Subsidies

\begin{tabular}{|c|c|c|c|c|}
\hline \multicolumn{1}{|c|}{} & \multicolumn{3}{c|}{$\begin{array}{c}\text { Scenario A: } \\
\text { Tax Expenditure }\end{array}$} & \multicolumn{2}{c|}{$\begin{array}{c}\text { Scenario B: } \\
\text { Direet Nontaxable Subsidy }\end{array}$} \\
\hline Taxpayer's Gross Income & $\$ 100$ & & $\$ 100$ & \\
\hline $\begin{array}{c}\text { Tax Paid to Government } \\
\text { (at 30 Percent of Gross Income) }\end{array}$ & & $(\$ 30)$ & & $(\$ 30)$ \\
\hline Tax Expenditure Received & & $\$ 20$ & & N/A \\
\hline Net Tax Paid to Government & & $(\$ 10)$ & & $(\$ 30)$ \\
\hline Taxpayer's After-Tax Income & $\$ 90$ & & $\$ 70$ & \\
\hline $\begin{array}{c}\text { Direct (Tax-Free) Subsidy } \\
\text { Received }\end{array}$ & & N/A & & $\$ 20$ \\
\hline Taxpayer's Ultimate Net Income & $\$ 90$ & & $\$ 90$ & \\
\hline $\begin{array}{c}\text { Government's Ulimate Net } \\
\text { Revenue }\end{array}$ & & $\$ 10$ & & $\$ 10$ \\
\hline
\end{tabular}

In Scenario $A$, the government collects $\$ 30$ in taxes from the individual. But the medical tax credit of $\$ 20$ reduces the net taxes collected by the government to $\$ 10$. The taxpayer pays a net $\$ 10$ to the government and keeps a net $\$ 90$.

In Scenario B, the government again collects $\$ 30$ in taxes from the individual. But this time the government pays $\$ 20$ to the taxpayer in the form of its direct medical subsidy. The end result again leaves the government with $\$ 10$, and the taxpayer with $\$ 90$.

Comparing these two scenarios shows that, for both the taxpayer and the government, a tax expenditure of $\$ 20$ is the economic equivalent of the government giving out $\$ 20$ directly. ${ }^{55}$

\section{APPLying THE FCA to PROTECT AGAINST TAX-EXPENDITURE FRAUD}

Although FCA actions have traditionally addressed fraud related only to direct payments by the federal government,${ }^{56}$ or the fraudulent

55. Politically, of course, the two programs are not equivalent, as has already been remarked upon. See supra note 4. Congress might prefer to adopt the tax expenditure to replace an alreadyexisting direct subsidy, since doing so will appear to cut spending (and taxes) and generally will not harm the subsidy's current constituency.

56. United States ex rel. Hopper v. Anton, 91 F.3d 1261, 1266 (9th Cir. 1996). The Anton court explains:

The archetypal qui tam FCA action is filed by an insider at a private company who discovers his employer has overcharged under a government contract. However, FCA actions have also been sustained under theories of supplying substandard products or 
retention of money directly owed to the government, ${ }^{57}$ we argue that the FCA's protection should also extend to false claims for payments made against funds that the government has subsidized indirectly through tax expenditures.

We appreciate that taxpayers who are defrauded of funds in their possession may already have ways to vindicate their rights individually, including traditional contract and tort causes of action. However, taxpayers face growing practical difficulties in pursuing such traditional claims, in part due to the widespread use of arbitration clauses that prohibit litigation altogether ${ }^{58}$ and in part because of judicial acceptance of contractual class-action waivers that can eliminate any ability to bring aggregated claims. ${ }^{59}$

Thus, using the FCA to target tax-expenditure fraud has certain advantages. For example, the government, which is the real party in interest in a qui tam FCA suit, ${ }^{60}$ is not bound by an arbitration clause that a qui tam relator has entered into in her personal capacity. ${ }^{61}$ Similarly, the government's unified interest in a large-scale fraud targeted at many diffuse recipients of a particular tax expenditure can be efficiently litigated by a single qui tam relator, even if the affected taxpayers have waived their individual rights to bring class actions. If we are correct that the FCA may be invoked to remedy frauds directed at government spending in the form of tax expenditures, then the FCA not only provides greater protection to the government than courts have recognized, but also offers relators a new way to vindicate

services; false negotiation, including bid rigging and defective pricing; and false certification.

Id. (footnotes omitted).

57. United States ex rel. Cafasso v. Gen. Dynamics C4 Sys., Inc., 637 F.3d 1047, 1056 (9th Cir. 2011) ("The 'reverse false claims' provision does not eliminate or supplant the FCA's false claim requirement; it rather expands the meaning of a false claim to include statements to avoid paying a debt or returning property to the United States.").

58. See generally Judith Resnik, Diffusing Disputes: The Public in the Private of Arbitration, the Private in Courts, and the Erasure of Rights, 124 YALE L.J. 2804, 2808 (2015) (lamenting the "mass production of arbitration clauses").

59. See generally Myriam Gilles \& Gary Friedman, After Class: Aggregate Litigation in the Wake of AT\&T Mobility v. Concepcion, 79 U. CHI. L. REV. 623, 629-30 (2012) (recognizing the enforcement gap likely to result from an "impending tsunami of class action waivers").

60. United States ex rel. Eisenstein v. City of New York, 556 U.S. 928, 930 (2009).

61. See, e.g., United States v. My Left Foot Children's Therapy, LLC, No. 214CV01786MMDGWF, 2016 WL 3381220, at *2 (D. Nev. June 13, 2016) (holding that a binding arbitration provision signed by a qui tam relator, but not the federal government, did not bind the government to arbitrate). 
individual and class rights as those become increasingly difficult to enforce through traditional mechanisms.

\section{A. The FCA Should Protect Tax Expenditures}

The FCA should be understood to protect the government against tax-expenditure fraud to the same degree that the law already protects the government against fraud in the context of direct spending.

In the case of tax expenditures, it is true that money typically does not directly flow from the treasury to private individuals. ${ }^{62}$ However, as noted in Part II, tax expenditures are economically equivalent to and affect the federal treasury in the same way as direct expenditures. ${ }^{63}$

Four dissenting Supreme Court Justices recently emphasized, at least in the context of a standing analysis, that there is little economic or policy distinction between direct spending and tax expenditures. They noted that the "novel distinction in standing law between appropriations and tax expenditures has as little basis in principle as it has in our precedent. Cash grants and targeted tax breaks are means of accomplishing the same government objective-to provide financial support to select individuals or organizations." ${ }^{64}$

62. Refundable tax credits are one obvious exception.

63. Of course, if the tentative taxes were less than twenty dollars in our example, then the effect of the tax credit and the grant would be different. However, even in that case, the effect would be to reduce the revenue of the government.

64. Ariz. Christian Sch. Tuition Org. v. Winn, 563 U.S. 125, 148 (2011) (Kagan, J., dissenting). The Court also explained in Regan v. Taxation with Representation of Washington that

[b]oth tax exemptions and tax-deductibility are a form of subsidy that is administered through the tax system. A tax exemption has much the same effect as a cash grant to the organization of the amount of tax it would have to pay on its income. Deductible contributions are similar to cash grants of the amount of a portion of the individual's contributions.

Regan v. Taxation with Representation of Wash., 461 U.S. 540, 544 (1983); see also Opinion of the Justices to the Senate, 514 N.E.2d 353, 355 (Mass. 1987) (noting in the case of Massachusetts tax expenditures that "the form of a tax deduction rather than a direct payment out of the Commonwealth's treasury does not alter the result, for it has been recognized that the tax subsidies or tax expenditures of this sort are the practical equivalent of direct government grants"). Statutory provisions also reflect the view that tax expenditures affect the federal treasury in the same way as direct spending. E.g., 2 U.S.C. $\S 632(\mathrm{e})(2)(\mathrm{E})(2012)$ (requiring Congress to include "the estimated levels of tax expenditures (the tax expenditures budget) by major items and functional categories for the President's budget" in its own annual concurrent resolution on the budget); 31 U.S.C. $\S 1105$ (a)(16) (requiring the President to include "the level of tax expenditures under existing law" in the annual budget submitted to Congress). But see Kotterman v. Killian, 972 P.2d 606, 619 (Ariz. 1999) (en banc) ("[The equivalence between tax expenditure and direct spending] has not, however, been universally accepted as a doctrine of judicial decisionmaking. Even the Supreme Court's treatment of the concept 'changes depending on the 
The Supreme Court has also recognized as a general matter that the chief purpose of the FCA is "to provide for restitution to the government of money taken from it by fraud." ${ }^{65}$ Favoring a very broad reading of the FCA, the Supreme Court has noted that " $[\mathrm{t}]$ his remedial statute reaches beyond 'claims' which might be legally enforced, to all fraudulent attempts to cause the Government to pay out sums of money." ${ }^{66}$ At the same time, the Court has cautioned that "it is equally clear that the False Claims Act was not designed to reach every kind of fraud practiced on the Government." ${ }^{67}$ Summarizing Supreme Court doctrine, the Eighth Circuit has concluded that "only those actions ... which have the purpose and effect of causing the United States to pay out money it is not obligated to pay, or those actions which intentionally deprive the United States of money it is lawfully due, are properly considered 'claims' within the meaning of the FCA."

substantive area of law being considered." (footnote omitted) (quoting Donna D. Adler, The Internal Revenue Code, the Constitution, and the Courts: The Use of Tax Expenditure Analysis in Judicial Decision Making, 28 WAKE FOREST L. REV. 855, 857 (1993))).

65. United States ex rel. Marcus v. Hess, 317 U.S. 537, 551 (1943). The Court has also noted that a "Senator discussing these sections said: 'The government ought to have the privilege of coming upon him (a fraudulent contractor) or his estate and his heirs and recovering the money of which it is defrauded." Id. at 552 (footnote omitted) (quoting CONG. GLOBE, 37th Cong., 3d Sess. 958 (1863) (statement of Sen. Grimes)).

66. United States v. Neifert-White Co., 390 U.S. 228, 233 (1968); see also United States ex rel. Jones v. Brigham \& Women's Hosp., 678 F.3d 72, 85 (1st Cir. 2012) ("[W]e take a broad view of what may constitute a false or fraudulent statement to avoid 'foreclos[ing] FCA liability in situations that Congress intended to fall within the Act's scope." (citation omitted)); United States ex rel. Hendow v. Univ. of Phx., 461 F.3d 1166, 1170 (9th Cir. 2006) ("[I]n amending the False Claims Act in 1986, Congress emphasized that the scope of false or fraudulent claims should be broadly construed."); United States v. Rivera, 55 F.3d 703, 709 (1st Cir. 1995) ("The paradigmatic example of a false claim under the FCA is a false invoice or bill for goods or services. The term, however, applies more generally to other demands for government funds.").

67. United States v. McNinch, 356 U.S. 595, 599 (1958).

68. Costner v. URS Consultants, Inc., 153 F.3d 667, 677 (8th Cir. 1998) (emphasis added); accord United States ex rel. Shupe v. Cisco Sys., Inc., 759 F.3d 379, 385 (5th Cir. 2014) ("[C]ases reveal[] that courts have limited the FCA's application to 'instances of fraud that might result in financial loss to the Government.'" (quoting United States ex rel. Sanders v. Am.-Amicable Life Ins. Co. of Tex., 545 F.3d 256, 259 (3d Cir. 2008))); United States ex rel. Vigil v. Nelnet, Inc., 639 F.3d 791, 795-96 (8th Cir. 2011) ("The FCA is not concerned with regulatory noncompliance. Rather, it serves a more specific function, protecting the federal fisc by imposing severe penalties on those whose false or fraudulent claims cause the government to pay money."); Hendow, 461 F.3d at 1174 ("[F]or there to exist a 'claim' for purposes of False Claims Act liability, it must involve merely some sort of request for the government to pay out money or forfeit moneys due."); Hutchins v. Wilentz, Goldman \& Spitzer, 253 F.3d 176, 184 (3d Cir. 2001) ("[T]he [FCA] seeks to redress fraudulent activity which attempts to or actually causes economic loss to the United States ... [T] The submission of false claims ... which do not or would not cause financial loss to the government are not within the purview of the [FCA]."); United States v. Azzarelli Constr. Co., 647 F.2d 757, 759 (7th Cir. 1981) ("[T]he allegedly false claim must be one that is 
The economic equivalence between tax expenditures and direct outlays suggests that the FCA should naturally be understood to extend to claims of fraud that target funds subsidized by tax expenditures. Such fraud "intentionally deprive[s] the United States of money it is lawfully due." ${ }^{69}$ Continuing with the scenarios previously discussed, suppose that the individual in Scenario A is a retiree who is defrauded of tax-favored retirement funds, while the individual in Scenario B is a state agency defrauded of federal disaster-relief funds. Both frauds misappropriate government spending. In Scenario A, the spending was accomplished through the tax code, whereas in Scenario $\mathrm{B}$, the spending was effected as a direct payment. There is no economic difference in the two scenarios but for the form. ${ }^{70}$

Tax-expenditure fraud should be regarded as equivalent to directexpenditure fraud under the FCA for two reasons. First, as already discussed, tax expenditures are the economic equivalent, for everyone involved, of the government making cash payments. Second, tax expenditures have a real impact on the treasury because they reduce revenues that the government would otherwise collect. Because the purpose of the FCA is to protect the public fisc from fraud, the language of the statute should be understood to reach frauds that target spending accomplished through the tax code, not just frauds that target spending in the form of direct expenditures. ${ }^{71}$

capable of causing an injury to the funds or property of the United States if the claim is in fact paid.").

69. Costner, 153 F.3d at 677 (declining to find this test satisfied where the fraud at issue targeted an environmental trust fund that had been created through a litigation settlement in which the government participated, but where none of the money came from or was reimbursed by the government and the government neither had access to nor control over the fund).

70. To clarify, note that the FCA "attaches liability, not to the underlying fraudulent activity or to the government's wrongful payment, but to the "claim for payment." United States v. Rivera, 55 F.3d 703, 709 (1st Cir. 1995).

71. See Hendow, 461 F.3d at 1174 ("[T] he precise logistical details of how the claim is made ... are immaterial.... [F]or there to exist a 'claim' for purposes of False Claims Act liability, it must involve merely some sort of request for the government to pay out money or forfeit moneys due."); United States ex rel. Main v. Oakland City Univ., 426 F.3d 914, 916 (7th Cir. 2005) ("The statute requires a causal rather than a temporal connection between fraud and payment .... If a false statement is integral to a causal chain leading to payment, it is irrelevant how the federal bureaucracy has apportioned the statements among layers of paperwork."); Peterson v. Weinberger, 508 F.2d 45, 52 (5th Cir. 1975) ("These provisions [of the FCA], considered together, indicate a purpose to reach any person who knowingly assisted in causing the government to pay claims which were grounded in fraud, without regard to whether that person had direct contractual relations with the government."). 


\section{B. Judicial Hostility to the Tax-Expenditure Theory}

Perhaps because the 2009 amendments to the FCA are so recent, courts have not often been called on to consider applications of the FCA similar to the one we are urging. But when they have done so, they have not been especially receptive. Two courts have explicitly rejected attempts to apply the FCA to tax expenditures. In Garg v. Covanta Holding Corp. ${ }^{72}$ the Third Circuit rejected an application of the FCA to tax expenditures because the court found that the alleged false claim did not sufficiently impact the government program or interest at issue..$^{73}$ In United States ex rel. McGuire v. Webster Bank, N.A. ${ }^{74}$ a federal magistrate judge in the U.S. District Court for the District of Colorado applied the reasoning in Garg to conclude that alleged false claims made against the tax-subsidized funds in account holders' health savings accounts had no consequence for the government or the treasury. ${ }^{75}$

1. Garg v. Covanta Holding Corp. In Garg, the Union County Utilities Authority (UCUA), a New Jersey instrumentality designated to handle solid waste, issued a series of federal tax-exempt bonds and hired Covanta to perform waste-management services. ${ }^{76}$ Alleging that Covanta submitted false claims to the UCUA, Sunil Garg, the executive director of the UCUA, filed an FCA claim against Covanta. ${ }^{77}$ Espousing a tax-expenditure theory somewhat similar to the one we advocate, Garg argued that the UCUA was a federal "grantee" because the deductibility of interest on its bonds amounted to a financial benefit conferred by the government. ${ }^{78}$

The Third Circuit acknowledged that the tax exemption for the UCUA's bonds benefited the UCUA (in addition to the bond purchasers) because the exemption made the bonds more attractive and thus led to the UCUA having "more money in its proverbial pocket (thanks to the federal government) than it would if it had to

72. Garg v. Covanta Holding Corp., 478 F. App'x 736 (3d Cir. 2012).

73. Id. at 742 .

74. United States ex rel. McGuire v. Webster Bank, N.A., No. 14-cv-00097-RM-CBS (D. Colo. Sept. 3, 2015), ECF No. 68.

75. Recommendation Regarding Defendant's Motion to Dismiss at 12 n.11, United States $e x$ rel. McGuire v. Webster Bank, N.A., No. 14-cv-00097-RM-CBS (D. Colo. Aug. 5, 2015), ECF No. 62 [hereinafter Recommendation].

76. Garg, 478 F. App'x at 738 .

77. Id. at $738-39$.

78. Id. at 739 . 
issue non-tax-exempt bonds at a regular interest rate," as Garg had argued. ${ }^{79}$ But the court rejected Garg's claim that this indirect benefit transformed the UCUA's own funds into the equivalent of a grant from the federal government for purposes of the FCA:

Even granting Garg this point-that UCUA has effectively received a direct financial subsidy from the federal government-his argument still fails. The FCA requires more than fraud against anyone who happens to receive money from the federal government....

Rather, the plain language of the FCA requires that there be some greater nexus between the alleged fraud and the government funds. ${ }^{80}$

Elaborating on this concept of nexus, the court further explained:

The FCA does not apply to fraud against any federal grantee; it requires that the specific money or property claimed must be intended to "be spent or used on the Government's behalf or to advance a Government program or interest." Furthermore, the federal government must also provide at least a portion of the specific "money or property requested" or reimburse the grantee for that specific demand. These statutory requirements all drive at the same point - that "the False Claims Act only prohibits fraudulent claims that cause or would cause economic loss to the government." "[O]nly actions which have the purpose and effect of causing the government to pay out money are clearly 'claims' within the purpose of the Act." ${ }^{\prime 81}$

As this passage indicates, the Garg court's real concern was the alleged fraud's apparent lack of impact on the federal treasury. ${ }^{82}$ This concern certainly appears valid, given the facts that the relator in Garg alleged. While the UCUA might have sold more bonds by virtue of the bonds' tax-exempt status, any connection between the proceeds from the UCUA's sale of its bonds, on one hand, and the revenues foregone by the federal government as a result of not taxing bondholders on

79. Id. at 740 .

80. Id. at 741 .

81. Id. (emphasis in original) (citations omitted) (quoting 31 U.S.C. $\$ 3729(\mathrm{~b})(2)(\mathrm{A})(\mathrm{ii})$ (2012)).

82. Any purported lack of government purpose underlying the tax exemption afforded to state and local bonds by 26 U.S.C. $\$ 103$ cannot justify the Third Circuit's rejection of Garg's case theory, for it is well established that the tax exemption for such bonds serves a government purpose of allowing states and localities to attract investment. See Holley v. United States, 124 F.2d 909, 911 (6th Cir. 1942) ("Congress established the exemptions in this section of the statute to aid in the flotation of government bonds and securities by making them tax free, and therefore more attractive to investors."). 
their income from those bonds, on the other, seems excessively remote. The definition of "claim" under the FCA still requires that the government must "(I) ... ha[ve] provided any portion of the money or property requested or demanded; or (II) will reimburse [the] contractor, grantee, or other recipient for any portion of the money or property which is requested or demanded." ${ }^{83}$ The relator in Garg's theory that the government's conferral of a tax-expenditure benefit on bondholders can somehow work to transform a bond issuer into a grantee of government money stretches the meaning of "nexus" too far. The mere fact that the UCUA partly finances itself through taxexempt bonds does not by itself make every fraud against the UCUA actionable under the FCA.

On the basis of Garg's facts, the Third Circuit correctly concluded that the asserted nexus between the funds targeted by Covanta's fraud and the federal treasury was too attenuated to support an FCA claim. ${ }^{84}$ However, while the Garg court rejected one application of the taxexpenditure theory, Garg's reasoning does not preclude the use of a tax-expenditure theory when there is a closer nexus between the funds targeted for fraud and federal money. The next case we discuss presents just such a fact pattern.

2. United States ex rel. McGuire v. Webster Bank, N.A. In Webster, a federal magistrate in the District of Colorado took a similarly dim view of the FCA's application to fraud targeted at a collection of private funds that had been subsidized by federal tax expenditures. ${ }^{85}$ In Webster, the relator (who is also one of the authors) alleged that the defendant bank violated the FCA by knowingly asserting a false contractual entitlement to charge thousands of Health Savings Accounts (HSA) under its administration a total of more than $\$ 1.4$ million in illegal monthly account-maintenance fees. ${ }^{86}$ An HSA is a tax-exempt trust established to pay certain qualified medical

83. 31 U.S.C. $\$ 3729(\mathrm{~b})(2)$.

84. See United States ex rel. Hendow v. Univ. of Phx., 461 F.3d 1166, 1172 (9th Cir. 2006). The opinion explains:

[S]tatement or course of conduct must be material to the government's decision to pay out moneys to the claimant. This is plain from our focus on "(1) whether the false statement is the cause of the Government's providing the benefit; and (2) whether any relation exists between the subject matter of the false statement and the event triggering Government's [sic] loss."

Id.

85. Recommendation, supra note 75 , at 4 .

86. Id. 
expenses; contributions to HSAs can be claimed as tax deductions ${ }^{87}$ The revenue foregone by the government to subsidize and promote the private funding of HSAs is therefore an example of a tax expenditure.

The complaint in Webster alleged that in September 2014, the bank illegally instituted account maintenance fees on previously exempt HSA balances. ${ }^{88}$ The bank's new fee structure was such that aggrieved account holders were left with no option but to pay the fees or close their accounts-and incur a termination fee even larger than the total of the new fees. ${ }^{89}$ The relator relied on common-law unconscionability and the prohibition of unfair practices set out in the Federal Trade Commission $\mathrm{Act}^{90}$ as grounds to allege that the new fees were unlawful. ${ }^{91}$ The complaint alleged that the bank's deduction of the fees from the balances of its account holders implied the existence of a contractual entitlement to payment of the fees. ${ }^{92}$ Because this implied certification of entitlement to be paid was legally false, the bank's claim on its customers' tax-subsidized HSA funds was therefore a false claim made to a grantee or other recipient of federal money under the FCA. ${ }^{93}$

The bank moved to dismiss the complaint for failure to state a claim under the FCA, relying heavily upon Garg to argue that the relator's tax-expenditure theory failed to allege any harm to the government fisc. ${ }^{94}$ The relator responded that the bank's confiscation of tax-subsidized funds was the equivalent of a false claim targeted at a fixed amount of federal grant money in the hands of a private grantee. ${ }^{95}$ The relator also argued that the bank's conduct did nonmonetary damage to the government in the form of "harm to the Federal Government's interest in the administration and integrity of its

87. 26 U.S.C. $\$ 223$ (2012).

88. Complaint for Violations of the Federal False Claims Act and of the New York False Claims Act and Jury Demand at 20, United States ex rel. McGuire v. Webster Bank, N.A., No. 14-cv-00097-RM-CBS (D. Colo. Jan. 1, 2014), ECF No. 1 [hereinafter Complaint].

89. Id. at $18-19$.

90. 15 U.S.C. $\S 45(\mathrm{a})(1)$.

91. Complaint, supra note 88 , at $19-20$.

92. Id. at 21 .

93. Id.

94. Webster Bank, N.A.'s Motion to Dismiss Relator's Complaint (Fed. R. Civ. P. 12(b)(6)) and Brief in Support at 17-20, United States ex rel. McGuire v. Webster Bank, No. 14-cv-00097RM-CBS (D. Colo. Aug. 4, 2014), ECF No. 32.

95. Relator's Response to Webster's Motion to Dismiss at 28-31, United States ex rel. McGuire v. Webster Bank, N.A., No. 14-cv-00097-RM-CBS (D. Colo. Sept. 12, 2014), ECF No. 35 [hereinafter Relator's Response]. 
tax expenditure program that favors the private funding of individual health savings accounts in violation of the [FCA]." 96

The magistrate judge was unreceptive to the relator's taxexpenditure theory, which he summarized as follows:

[Relator] postulates that moneys held in a health savings account constitute "tax expenditures" and represent the practical equivalent of payments by the United States because the corresponding tax deductions advance a government policy. As [Relator] explains, "every single dollar that is contributed to [a health savings account] is a dollar that the Government would have taxed, but has instead refrained from taxing. Such dollars fully represent 'revenue losses' to the Treasury." 97

Rejecting the claim that a nexus existed between the private funds held in HSAs and the public fisc, the magistrate judge noted:

[T] he Complaint in this case does not describe any actions or statements by Webster Bank that would meet the definition of "claim," or allege any facts that suggest the United States Government either received a demand for payment related to [Relator's] health savings account or provided any of the funds in the Relator's account. ${ }^{98}$

He explained, "it is reasonable to conclude that Congress believes that encouraging health-related savings is a laudable policy objective that can be promoted by providing tax-incentives to the same taxpayers who fund the savings accounts. Those tax-incentives do not transform the account balances into 'federal funds' or payments by the government." 99

Persuaded by the bank's view of the reasoning in Garg, the magistrate judge held that a "fair reading of the Complaint makes clear that [the Relator] is attempting to transform a garden variety breach of contract or fraud claim against Webster Bank into a scheme to defraud the government. The FCA cannot be applied so broadly." 100 Of particular significance to the magistrate was the fact that "under the Relator's 'tax expenditure' theory ... any potential revenue losses to

\footnotetext{
96. Recommendation, supra note 75 , at 5 (quoting Complaint, supra note 88 , at 30 ).

97. Id. at 11-12 (third alteration in original) (quoting Relator's Response, supra note 95, at 20).

98. Id. at 9.

99. Id. at 13 .

100. Id. at 14 .
} 
the Treasury occurred at the time [the Relator] lawfully contributed to his health savings account... . [A]ny subsequent withdrawals from that same account ... had no tax consequences for [the Relator] or the Treasury." 101

But one of the reasons why Congress amended the FCA in 1986 was to foreclose precisely such determinations that fraud against funds already in the hands of a third party could not impact the treasury. Prior to the 1986 amendments, fraud against fixed sums of government money in the hands of third-party grantees had been held not to impact the treasury and, therefore, not to implicate the FCA's protections. In United States v. Azzarelli Construction Co.,${ }^{102}$ contractors involved in a highway construction project were accused of defrauding the state of Illinois by engaging in a bid-rigging conspiracy. ${ }^{103}$ The Seventh Circuit held that an FCA action could not proceed against the contractors; because the federal contribution to the state highway project was a fixed sum, the treasury could not possibly be impacted by a fraud that did nothing to affect the size of the federal contribution. ${ }^{104}$ Congress disagreed with this reasoning. When Congress amended the FCA in 1986, it expressly noted its intention to overturn Azzarelli by defining the term "claim" to include requests for money submitted to federal "grantees," thereby ensuring that the FCA covered fraud against "State, local or private programs funded in part by the United States where there [was] significant Federal regulation and involvement." 105

The government's tax expenditure in Webster is conceptually indistinguishable from the fixed grant made to the state of Illinois in Azzarelli. Both expenditures impacted the treasury in a fixed amount and did so independently of the fraud at issue in the case. Neither expenditure increased as a result of the fraud directed at the third-party grantee or other recipient. The definition of "claim" at issue in Webster was materially the same as the definition Congress adopted to overrule the result in Azzarelli. Accordingly, if the false claims in Azzarelli are now actionable under the FCA, then the false claims alleged in Webster

101. Id. at 12 n.11.

102. United States v. Azzarelli Constr. Co., 647 F.2d 757 (7th Cir. 1981).

103. Id. at 758 .

104. Id. at $760-62$.

105. S. COMM. ON THE JUdiCIARY, FALSE ClAIMS AMENDMENTS ACT OF 1986, S. REP. No. 99-345, at 22 (1986), reprinted in 1986 U.S.C.C.A.N. 5266, 5267 ("Thus, the Committee intends the new subsection (d) to overrule Azzarelli and similar cases which have limited the ability of the United States to use the act to reach fraud perpetrated on federal grantees, contractors or other recipients of Federal funds."). 
should be too, so long as tax expenditures are properly regarded as equivalent to direct spending.

On this point, it is problematic that the magistrate in Webster did not give any weight to the economic equivalency between tax expenditures and direct spending. He chose to focus instead on the difference in timing between when the tax expenditure impacted the treasury and when the alleged fraud affected the relator's taxsubsidized funds.

As illustrated by Scenarios A and B above, there is no economic difference between the government granting the relator a tax deduction for the amount of the relator's private contribution into an HSA and the government making a direct payment to reimburse the relator for a certain portion of the relator's contribution. On what rational basis should the government's reduction in revenue due to allowing a deduction of the relator's contribution into an HSA not be protected by the FCA if the government's direct reimbursement of an equivalent portion of the same contribution plainly would be protected? False claims targeting a fixed amount of tax-subsidized funds in an HSA do the same kind of harm to the treasury - and to the government's programmatic interests-as did the false claims in Azzarelli, which targeted a fixed amount of directly subsidized funds. ${ }^{106}$

Based on the language of the FCA, it does not matter whether the false claim against the relator's tax-subsidized funds only occurred after the tax subsidy for the relator's HSA contributions impacted the treasury. Nothing in the statute imposes such a temporal limitation. ${ }^{107}$ The very same timing issue (that is, fraud occurring after the impact on the public fisc) arises whenever a grantee is defrauded of grant funds that the government has previously disbursed. The timing of a false claim's impact on the treasury simply does not matter; $; 08$ all that does matter for claims made to contractors, grantees, and other recipients

106. In explaining the 1986 legislative amendments to the FCA that overruled Azzarelli, courts have recognized that "the Senate Judiciary Committee made clear that it intended the concept of loss to the United States to be considered broadly." United States ex rel. Yesudian v. Howard Univ., 153 F.3d 731, 739 (D.C. Cir. 1998); see also, e.g., id. ("Congress, then, plainly regarded a false claim as causing a loss to the United States in the Azzarelli situation, notwithstanding that the false claim would not lead to an additional pay-out of federal funds.").

107. Moreover, courts have expressly rejected any requirement for a temporal connection between fraud and payment. See, e.g., cases cited supra note 71.

108. Indeed, recovery under the FCA does not require the government to actually sustain any monetary damages at all. Varljen v. Cleveland Gear Co., 250 F.3d 426, 429 (6th Cir. 2001). Only the potential for the treasury to be impacted must be present. See Hutchins v. Wilentz, Goldman \& Spitzer, 253 F.3d 176, 183 (3d Cir. 2001). 
of government money is that the government "provides," "has provided," or "will reimburse ... any portion of the money or property which is requested or demanded." 109

The economic equivalence of tax expenditures and direct expenditures, coupled with the fact that the federal government allows deductions for HSA contributions for the public purpose of encouraging private funding of HSAs, suggests that the kind of fraud alleged in Webster should be actionable under the FCA. ${ }^{110}$

\section{Concerns with the Tax-Expenditure Theory}

Garg and Webster stand as obstacles to the proposition that FCA claims properly include fraud directed at private funds in private hands that are, in substance, subsidized by government tax expenditures. However, the economic equivalency between direct government expenditures, which unquestionably fall under the scope of the FCA, and spending accomplished through tax expenditures suggests that both forms of government spending should receive the FCA's protections. This outcome best serves the FCA's intended purpose of "provid[ing] for restitution to the government of money taken from it by fraud." "111

The courts' most serious concern about applying the FCA to tax expenditures seems to be that it would unduly expand the scope of the FCA and open a floodgate of litigation. Indeed, the Garg court wrote:

[If we accept the tax-expenditure theory] the scope of the FCA would be enormous. Nearly every adult American receives a "subsidy" from the federal government, be it direct or indirect. In the tax realm alone, every taxpaying American receives some form of exemption or deduction, such as the home mortgage interest deduction, the charitable contributions deduction, or even simply the standard deduction. Just like the tax-exempt bonds, the government's decision to grant these deductions is a matter of grace, and the money saved by these deductions goes straight to the bottom-line of the American taxpayer. Moreover, some of us receive our paychecks from the

109. 31 U.S.C. \& 3729(b)(2) (2012).

110. Given the decision of the United States to decline intervention, the court's evident displeasure with the tax-expenditure theory, and the defendant's request for fee shifting, the relator ultimately opted to dismiss the Webster case voluntarily, rather than pursue it to a potentially adverse final judgment. Order Granting Unopposed Motion for Voluntary Dismissal at 4, United States ex rel. McGuire v. Webster Bank, N.A., No. 14-cv-00096-RM-CBS (D. Colo. Sep. 3, 2015), ECF No. 68.

111. United States ex rel. Marcus v. Hess, 317 U.S. 537, 551 (1943). 
federal government. That does not mean, however, that every fraud against a government employee or taxpayer supports a claim under the FCA. ${ }^{112}$

The objection that using the FCA against tax-expenditure fraud will expand the statute beyond appropriate limits is unwarranted. For one thing, when Garg was decided the FCA already defined "claim" in a manner that excluded fraud directed at federal salaries and unrestricted income subsidies from the law's reach. ${ }^{113}$ For another thing, the FCA already has a very broad reach with respect to direct expenditures. ${ }^{114}$ Concerns similar to those expressed in Garg have been raised in the context of direct expenditures-and properly rejected-because courts understand that "Congress means what it says and thus the statutory language is normally the best evidence of congressional intent." 115

However, to the extent that the Third Circuit's concerns in Garg are shared by sister courts considering whether the FCA applies to taxexpenditure fraud, solace may be found in two other constraints that

112. Garg v. Covanta Holding Corp., 478 F. App'x 736, 741 (3d Cir. 2012); see also Hutchins, 253 F.3d at 184 n.5. The Hutchins court explained that

[e]xtending the False Claims Act to reach any false statement made to the government, regardless of any impact on the United States Treasury, would appear to impermissibly expand standing doctrine and essentially permit any plaintiff to sue on behalf of the government when false or misleading statements are made to any government agent including the courts, the legislature or any law enforcement officer. Id.

113. 31 U.S.C. $\$ 3729(b)(2)(B)$.

114. See, e.g., United States ex rel. Oliver v. Philip Morris USA Inc., 763 F.3d 36, 38 (D.C. Cir. 2014) (imposing liability for selling cigarettes to corporate affiliates at prices lower than the contractual most-favored-customer pricing offered to military exchanges); United States v. Sci. Applications Intern. Corp., 626 F.3d 1257, 1273 (D.C. Cir. 2010) (imposing liability for failure to avoid and disclose conflicts of interest per contractual requirements); United States ex rel. Longhi v. United States, 575 F.3d 458, 467-68 (5th Cir. 2009) (imposing liability for a false statement about small-business eligibility in a grant proposal even when no false claims for payment were submitted); United States ex rel. Bahrani v. Conagra, Inc., 465 F.3d 1189, 1203 (10th Cir. 2006) (holding that liability for a reverse false claim could arise from avoiding government fees by correcting meat export certificates rather than obtaining new ones); United States ex rel. Krahling v. Merck \& Co., Inc., 44 F. Supp. 3d 581, 594 (E.D. Pa. 2014) (imposing liability for failure to disclose material information about safety and efficacy of vaccine while submitting claims for payment for government's purchase of the vaccine); Pickens v. Kanawha River Towing, 916 F. Supp. 702, 708 (S.D. Ohio 1996) (imposing liability for making a false record that was material to the recordmaker's obligation to pay fines to the government, where a tugboat captain failed to record the discharge of a pollutant into the Ohio River in violation of the Clean Water Act).

115. See, e.g., United States ex rel. Costa v. Baker \& Taylor, Inc., No. C-95-1825-VRW, 1998 WL 230979, at *8 (N.D. Cal. Mar. 20, 1998) ("Defendants' policy arguments regarding the potentially limitless reach of the False Claims Act under this reading of $\S 3729(\mathrm{c})$ should be addressed to Congress, not the court."). 
exist within the statute and that can be relied upon to prevent any excessively broad application of the FCA. First, the FCA requires scienter, ${ }^{116}$ so false statements must be knowingly false. Second, the FCA requires that the falsity of a claim be material to the payment decision of the government or (in the tax-expenditure context) the defrauded taxpayer. ${ }^{117}$

The materiality requirement, in particular, is sufficient to cabin the FCA to reasonable applications. As the Supreme Court has recently held, "[t]he materiality standard is demanding," finding of materiality requires more than minor or insubstantial noncompliance with a particular statutory, regulatory, or contractual requirement that has been designated to be a condition of payment. ${ }^{119}$ Materiality, moreover, is a concept that would readily apply to evaluating whether the funds targeted by the fraud in a tax-expenditure claim under the FCA have any meaningful connection to, and thus any impact on, the treasury.

The FCA's definition of "claim" should be read in a way that not only reflects economic substance, but also promotes the purposes for which the statute was enacted in the first place. Given the scienter and materiality requirements that apply in all FCA cases, a floodgate of litigation is unlikely to open as a result of recognizing that false claims against funds subsidized by tax expenditures are properly within the ambit of the FCA's protection.

To the extent that a limiting principle must be articulated in anticipation of courts' concerns about the potential breadth of applying the FCA to tax-expenditure frauds, the concept of nexus, touched on by Garg, appears to serve best. Requiring a sufficiently strong nexus between a tax expenditure and the funds used to pay a false claim will permit courts to screen FCA cases for overly attenuated connections to federal money, like the thin connection that the court rejected in

116. Hindo v. Univ. of Health Scis./Chi. Med. Sch., 65 F.3d 608, 613 (7th Cir. 1995) ("Turning to the substantive issue in this case, the False Claims Act imposes liability on one who 'knowingly presents' to the United States government 'a false or fraudulent claim for payment' .... Innocent mistakes or negligence are not actionable under this section." (citation omitted) (quoting 31 U.S.C. $\$ 3729$ (a) (2012))).

117. See United States ex rel. Garbe v. Kmart Corp., No. 15-1502, 2016 WL 3031099, at *4-5 (7th Cir. May 27, 2016) ("Kmart's misstatements had to be 'capable of influencing [] the decisionmaking body to which [they were] addressed." (alterations in original) (quoting Neder v. United States, 527 U.S. 1, 16 (1999))).

118. Universal Health Servs., Inc. v. United States ex rel. Escobar, 136 S. Ct. 1989, 2003 (2016).

119. Id. 
Garg. Nexus is a concept with which courts are well acquainted, and fashioning appropriate boundaries on the basis of nexus is an exercise that courts should be quite comfortable performing. Under a nexus test, an FCA action based on the facts in Garg would not be sustainable because an insufficient nexus exists between the tax expenditure at issue (a tax exemption granted to purchasers of the UCUA's bonds) and the funds that were used to pay the false claims (the UCUA's own revenues from all sources). In contrast, an FCA action based on the facts in Webster would be sustainable because a much closer nexus exists between the relevant tax expenditure (a tax deduction granted to HSA beneficiaries tied to the size of their contributions into a segregated account) and the funds used to pay the alleged false claims (the actual funds residing in that segregated account).

Finally, it is important to clarify why the FCA's Tax Bar would not apply to many tax-expenditure frauds. Recall that in Lissack, ${ }^{120}$ the test for determining whether the Tax Bar deprives a court of jurisdiction over an FCA case asks (1) whether establishing the "falsity of the claim ... depends entirely upon establishing a violation of the Tax Code," and (2) whether "the IRS has authority to recover" the funds sought. ${ }^{121}$

Under this two-prong test, some FCA cases involving fraud directed at government spending done through tax expenditures may be barred, but other cases will certainly be permitted to proceed. Tax expenditures, after all, are only incidentally about taxes; they are primarily about spending. Whenever a fraud involving tax expenditures is not subject to an enforcement action by the IRS, which would likely be true in many cases in which the fraudfeasor is someone other than the taxpayer, the Tax Bar will not apply because the fraud itself does not involve any violation of the tax code. In Webster, for example, the relator argued that the bank's alleged false claims against HSA funds had no connection to the tax code and, in fact, involved matters that the IRS itself expressly regarded to be matters of private contract between the taxpayer and the HSA administrator. ${ }^{122}$ Because the magistrate held that the relator failed to state a claim under the

120. See supra notes $41-45$ and accompanying text.

121. United States ex rel. Lissack v. Sakura Glob. Capital Mkts., Inc., 377 F.3d 145, 157 (2d Cir. 2004).

122. Relator's Response, supra note 95, at 21-22. 
FCA, the court did not reach the issue of whether the Tax Bar applied, and the relator's argument went unaddressed. ${ }^{123}$

In sum, Garg and Webster should not prevent the use of the FCA to attack false claims directed at funds subsidized by government tax expenditures. Garg is entirely consistent with our understanding of the FCA, and we would respectfully argue that Webster was wrongly decided.

\section{Potential Applications}

The legal requirements for scienter and materiality under the FCA, as well as our proposed requirement that there be a sufficient nexus between the defrauded funds and the treasury, combine to prevent our tax-expenditure theory from being applied in a manner that might transform a "garden variety breach of contract or fraud claim ... into a scheme to defraud the government." 124 In addition, many imaginable kinds of fraud "against a government employee or taxpayer" would not support FCA claims even under our theory. ${ }^{125}$

On the other hand, a broad variety of frauds that are inimical to the government's tax-expenditure goals would, under our theory, be newly actionable. Indeed, the Office of Management and Budget's list of 169 different tax expenditures suggests a plethora of possibilities. ${ }^{126}$ For example, the size of federal tax expenditures attributable to allowing deduction of employer contributions for medical insurance premiums and medical care was nearly $\$ 211$ billion in 2016 . Provider frauds that involve inflating the costs of covered healthcare could be actionable under a tax-expenditure theory of the FCA. Similarly, the cost of federal tax expenditures for the home mortgage interest deduction was $\$ 62$ billion in 2016. Lender frauds that involve inflating the costs of mortgage loans could be pursued under our theory. Tax expenditures that subsidize private contributions to individual retirement accounts totaled nearly $\$ 17$ billion in 2016. Account providers that fraudulently inflate account fees could be subject to FCA actions under our theory. Finally, tax expenditures attributable

123. Recommendation, supra note 75 , at 5 n.9.

124. Id. at 14.

125. Garg v. Covanta Holding Corp., 478 F. App'x 736, 741 (3d Cir. 2012).

126. Office of MGMt. \& Budget, Exec. Office of the President, Analytical PERSPECTIVES, BUDGET OF THE UNITED STATES GOVERNMENT, FISCAL YEAR 2017, supra note 54, at 243; OfFice of MGMT. \& Budget, ANAlytical Perspectives, TAX EXPENDITURES, supra note 54. 
to charitable contributions exceeded $\$ 10$ billion in 2016. Frauds targeting the tax-subsidized funds accumulated in charities could be actionable as tax-expenditure frauds.

Other potential examples abound. The common thread in these few imagined examples is a third-party fraudster who knowingly and materially defrauds a taxpayer of funds that the government has economically subsidized by means of tax expenditures. Under our taxexpenditure theory, the FCA would be available as a remedy for such frauds. The Tax Bar would not be an obstacle, for in the cases we imagine above, the defrauded taxpayer is not falsely reporting anything to the IRS - indeed, the taxpayer (like the government) is a victim of the fraud. Just as FCA actions lie when government grantees are hoodwinked into paying too much for grant-related goods and services, so too should the FCA be invoked when recipients of tax credits and deductions are hoodwinked into paying too much for tax-expenditurerelated goods and services.

\section{CONCLUSION}

We have argued for an understanding of the FCA that construes the term "claim" in a way that both reflects economic reality and promotes the FCA's purpose of protecting government money. Recognizing that tax expenditures are the substantive equivalent of direct expenditures for all relevant purposes under the FCA will achieve this result.

While we have made out a plausible claim that a broad variety of tax-expenditure frauds can be reached by the existing FCA, our argument might also be reframed as a call for law reform. Even if judicial reluctance ultimately means that the FCA as currently written cannot be invoked to attack tax-expenditure fraud, the law should be strengthened by Congress so that it can. The FCA's definition of "claim" might be usefully amended to eliminate any doubt that taxexpenditure frauds are within the scope of the statute. Such a reform would be consistent with the history of amendments that have systematically expanded the scope of the FCA's protection of the public fisc. Finally, while this Article has focused on the FCA as a vehicle for vindicating tax-expenditure fraud, an analogous exercise might be undertaken with regard to other whistleblower mechanisms, 
such as the Dodd-Frank Whistleblower Program. ${ }^{127}$ Recognition of the economic equivalence between tax expenditures and direct expenditures need not be confined to the context of the FCA alone.

Our approach to the FCA is a relatively untested one. Few courts have analyzed whether a false claim made against funds that have been effectively subsidized by tax expenditures may give rise to an actionable claim under the FCA. Our argument that tax-expenditure fraud does properly lie within the FCA's scope is consistent with both the language and the purpose of the statute. Our approach has the benefit of permitting taxpayers, in their capacity as qui tam relators, to vindicate fraud claims that may otherwise be unavailable in the face of binding arbitration clauses and contractual class-action waivers. At the same time, our reading of the FCA empowers the federal government to protect more than one trillion dollars of spending that is accomplished through the tax code. We urge courts to consider, and practitioners to explore, the possibilities.

127. Final Rules Implementing Whistleblower Provisions of Section $21 \mathrm{~F}$ of the Securities Exchange Act of 1934,17 C.F.R. $\$ \S 240,249$ (2015). The IRS also has a whistleblower mechanism provided by statute, 16 U.S.C. $\$ 7623$ (a) (2012), and implemented in the regulations, 26 C.F.R. $\$ 301.7623-1$ (2015), but the IRS program is unlikely to be an effective mechanism for addressing third-party tax-expenditure fraud when the taxpayer is a victim of the fraud, rather than its perpetrator. 


$$
* * *
$$

